\title{
Spatial distribution of benthic macrofauna in subtidal sediments of the Ría de Aldán (Galicia, northwest Spain)
}

\author{
ANTÍA LOURIDO $^{1}$, JUAN MOREIRA ${ }^{2}$ and JESÚS S. TRONCOSO ${ }^{1}$ \\ ${ }^{1}$ Departamento de Ecoloxía e Bioloxía Animal, Facultade de Ciencias do Mar, Campus de Lagoas-Marcosende s/n, \\ Universidade de Vigo, E-36310 Vigo, Spain. E-mail: antial@uvigo.es \\ ${ }^{2}$ Estación de Bioloxía Mariña da Graña, Universidade de Santiago de Compostela, Casa do Hórreo, Rúa da Ribeira 1, \\ E-15590 A Graña, Ferrol, Spain.
}

\begin{abstract}
SUMMARY: In the summer of 1997, 27 subtidal stations were quantitatively sampled in the Ría de Aldán. A total of 81770 individuals were collected, comprising 496 species. The distribution and composition of benthic assemblages was correlated to the sedimentary characteristics which, in turn, depend on the hydrodynamic features; those patterns are reflected in a sedimentary gradient present along the ria, which is characterized by an increasing grain size from the inner margins towards the mouth. Several faunal assemblages were determined through multivariate analyses and their composition is compared with that of several communities or facies previously described from similar sediments. The Venus fasciata community was present in clean coarse sediments of the outer ria, the Venus gallina and Tellina fabula-Tellina tenuis communities in the fine-sand bottoms at the centre and margins of the ria, a transition assemblage between the Venus fasciata and the Venus gallina communities in the medium-sand sediments, and a mix of species from the Syndosmya alba and the Amphiura communities in shallower and muddy sediments in the inner areas. In general, subtidal sediments of the Ría de Aldán showed a high benthic diversity which is related to the great sedimentary heterogeneity and the lack of significant anthropogenic
\end{abstract} alterations.

Keywords: benthic macrofauna, assemblages, soft bottoms, subtidal, Atlantic Ocean, Ría de Aldán.

RESUMEN: DistribuCión ESPACIAL DE LA MACROFAUna BENTÓNICA DE SEDIMENTOS SUBMAREALES DE La Ría DE ALDÁN (GALICIA, NoROESTE DE EsPAÑA). - Durante el verano de 1997, se hicieron muestreos en 27 estaciones submareales de modo cuantitativo en la Ría de Aldán. Se recolectaron un total de 81770 individuos, pertenecientes a 496 especies. Los análisis multivariantes permitieron distinguir varias asociaciones faunísticas cuya composición puede ser referida a comunidades o facies previamente descritas de sedimentos similares: la comunidad de "Venus fasciata" está presente en sedimentos limpios de granulometría gruesa de la parte externa de la ría, las comunidades de "Venus gallina" y "Tellina fabula-Tellina tenuis" aparecen principalmente en arena fina en las áreas marginal y central, una fauna de transición entre las comunidades de $V$. fasciata y $V$. gallina se encuentra en fondos de arena media, y los fondos someros fangosos de la zona interna están caracterizados por una mezcla de especies propias de las comunidades de "Syndosmya alba" y "Amphiura". En general, los sedimentos submareales de la Ría de Aldán presentaron una alta diversidad bentónica relacionada con la gran heterogeneidad sedimentaria y la ausencia de perturbaciones humanas significativas.

Palabras clave: macrofauna bentónica, asociaciones, sustratos blandos, submareal, Océano Atlántico, Ría de Aldán.

\section{INTRODUCTION}

Intertidal and shallow subtidal soft-sediment habitats constitute a small proportion of marine soft sediments (Ellis et al., 2000). They are, however, very productive and comprise a wide variety of habitats inhabited by a number of macrobenthic communities. Moreover, benthic faunas in coastal areas play important roles in providing food for humans, fish and birds (Ellis et al., 2000). In particular, macrofaunal activ- 
ity influences ecosystem processes such as nutrient cycles (carbon, nitrogen and sulphur), metabolism of pollutants and transport, and dispersion and burial of sediments (Snelgrove, 1998). The composition and diversity of macrofaunal assemblages must be studied in order to determine local and regional diversity patterns (Labrune et al., 2008). In addition, analysis of taxonomic diversity at the species level is a prerequisite in routine monitoring studies and helps to understand the functioning of a particular community because each species is characterized by an ecological role (Maggiore and Keppel, 2007).

During the last few years, there has been an ongoing interest in the Galician rias (NW Iberian Peninsula), because they are a special and complex kind of estuarine system with high primary productivity due to upwelling and regular input of nutrients (Nombela et al., 1995). The Galician rias have a great economic and social importance due to the presence of fisheries, bivalve culture and shellfish resources (Nombela et al., 1995; Figueiras et al., 2002). A number of activities resulting from the growing human population concentrating on the shoreline of the rias, such as mollusc harvesting, construction of artificial structures and sewage disposal, are heavily impacting marine sedimentary environments. For example, extensive culture on rafts of the blue mussel, Mytilus galloprovincialis Lamarck, 1819 in the rias of southern Galicia has resulted in alterations to the benthic environment in many areas (Abella et al., 1996). Indeed, mussels produce large amounts of faeces and pseudofaeces which are deposited on the bottoms right beneath them (López-Jamar, 1981), often producing organic enrichment, hypoxia and changes in granulometric composition. In general, the aforementioned perturbations result in changes in the composition of benthic assemblages and impoverishment of local biodiversity (López-Jamar and Mejuto, 1988). Therefore, studying the distribution and composition of benthic assemblages in the Galician rias is paramount in order to determine the status of the sediments and the degree of perturbation when they are subjected to anthropogenic activities (López-Jamar and Mejuto, 1986).

The composition and distribution of soft-bottom benthos are well-known in many areas of the Galician coast (e.g. López-Jamar and Cal, 1990; Mora et al., 1982; López-Jamar and Mejuto, 1985; Garmendia et al., 1998). There is, however, a lack of studies in some small rias such as the Ría de Aldán. In fact, the ecological catastrophe which affected most of the northern coast of Spain derived from the Prestige oil spill (November 2002) has revealed the lack of baseline data about benthic diversity and assemblages in many areas of the Galician coast; these data are needed in order to establish the true effect of these and other disturbances on the marine environment and determine whether the biota is recovering.

The Ría de Aldán is located at the mouth of the Ría de Pontevedra and shows a variety of subtidal sedi- ments, ranging from gravel to mud, at depths of up to $45 \mathrm{~m}$. These physical features offer a good opportunity to study the patterns of distribution and composition of benthic assemblages across several sedimentary substrata at a relatively small spatial scale $(<10 \mathrm{~km})$. In addition, in the last years the Ría de Aldán has been subjected to bivalve culture on rafts in some areas. Therefore, the main aims of this paper are: i) to characterize the composition and distribution of the macrobenthic fauna $(>0.5 \mathrm{~mm})$ of the subtidal soft bottoms of the Ría de Aldán in order to provide baseline data for further comparative studies; ii) to determine the possible relation of several environmental variables to the distributional patterns of the benthic fauna; and iii) to compare the benthic biodiversity of the Ría de Aldán with that of other similar geographic areas in order to assess its ecological value. Ultimately, these data might serve to develop proper strategies for management and conservation of soft-bottom benthic habitats.

\section{MATERIALS AND METHODS}

\section{Study area}

The Ría de Aldán is located in Galicia, between $42^{\circ} 16^{\prime} 40^{\prime \prime}$ and $42^{\circ} 20^{\prime} 50^{\prime} ' \mathrm{~N}$ and $8^{\circ} 49^{\prime}$ and $8^{\circ} 52^{\prime} \mathrm{W}$. This ria is located on the southern margin of the mouth of the Ría de Pontevedra (Fig. 1), and is $7 \mathrm{~km}$ long and $3.5 \mathrm{~km}$ wide. The Ría de Aldán has a maximum depth of $45 \mathrm{~m}$, and its mouth is oriented northwards. The small Aldán River flows into the inner area, and there is an increase in salinity from the internal to the external part of the ria. The effect of this freshwater input is reduced by the strong oceanic swell and currents which reach the inner areas. Both margins of the ria are made up of rocky substratum which alternates with sandy beaches. There is a growing practice of bivalve culture on rafts in the inner parts of the ria. This activity is assumed to contribute to the increase of the content of silt/clay and organic matter in those areas, as occurs in other Galician rias.

\section{Sample collection and processing}

Quantitative sampling was done in the Ría de Aldán in July-August 1997 at 27 subtidal sites, thus covering the full extent of the subtidal domain of the ria. Samples were taken by means of a van Veen grab with a sampling area of $0.056 \mathrm{~m}^{2}$; five replicates were taken at each site, accounting for a total area of 0.28 $\mathrm{m}^{2}$. Samples were sieved through a $0.5 \mathrm{~mm}$ mesh and fixed in $10 \%$ buffered formaldehyde solution. Fixed material was later taken to the laboratory for sorting and identification of the fauna.

Granulometric composition, calcium carbonate and organic matter content was also analysed from an additional sediment sample collected at each site. The granulometric fractions were considered following the Wentworth scale (1922) and sediment types were char- 

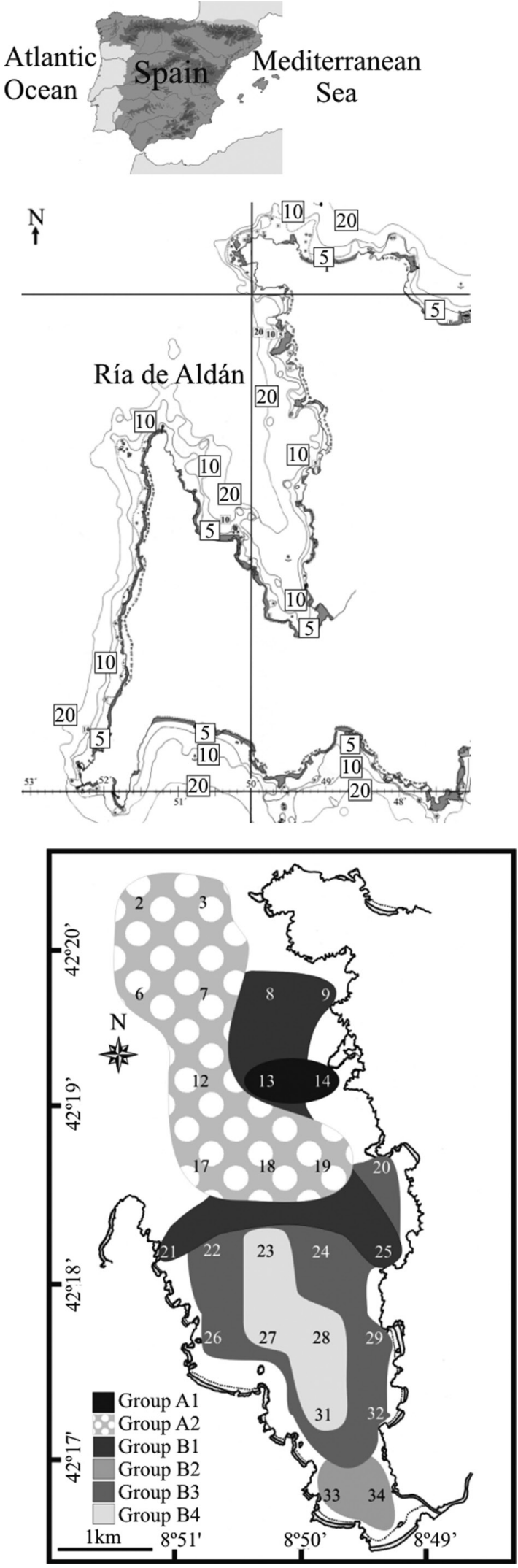

FIG. 1. - Location of the Ría de Aldán (Galicia, NW Spain), and position of the 27 sampling stations with the spatial distribution of faunal assemblages as determined by multivariate analysis. acterized according to Junoy (1996). Moreover, median grain size $\left(Q_{50}\right)$ and sorting coefficient $\left(S_{0}\right)$ (Trask, 1932) were also determined for each sample. Temperature, Eh and $\mathrm{pH}$ were measured in situ in the sediment, as was the temperature of surface and bottom water. Calcium carbonate content $(\%)$ was estimated by treating the sample with hydrochloric acid, and the total organic matter content (TOM, \%) was estimated from the weight loss on combustion for $4 \mathrm{~h}$ at $450^{\circ} \mathrm{C}$ (Table 1 ).

\section{Data analysis}

Total abundance $(\mathrm{N})$, total number of species $(\mathrm{S})$, the Shannon-Wiener diversity index $\left(\mathrm{H}^{\prime}\right.$, as $\left.\log _{2}\right)$ and Pielou's evenness (J') were calculated for each sampling station. At any given station, the species representing $4 \%$ or more of the total abundance were considered as numerically dominant (Field et al., 1982).

Faunal assemblages were determined through nonparametric multivariate techniques as described by Field et al. (1982) using the Plymouth Routines in the Multivariate Ecological Research software package (PRIMER; Clarke and Warwick, 1994). A similarity matrix between stations was prepared by means of the Bray-Curtis similarity coefficient after applying the fourth root transformation on the average abundance of each species (mean of five replicates) to reduce the contribution of the most abundant species. From the similarity matrix, a classification of the stations was done by cluster analysis developed from the groupaverage sorting algorithm and an ordination by means of non-metric multidimensional scaling (nMDS). The SIMPER program was then used to identify species that contributed highly to differentiating groups of stations determined by classification and ordination analyses. Species were classified according to the product frequency x dominance (Glémarec, 1964), which evaluates the constancy and the numerical importance of each species within a group of stations.

The potential relationship between faunal distribution in the ria and the estimated environmental variables was studied using the BIO-ENV procedure (belonging to the PRIMER package), and canonical correspondence analysis (CCA, using the CANOCO v4.02, Canonical Community Ordination package; Ter Braak, 1988). All variables expressed in percentages were previously transformed by $\log (x+1)$, and then all of them were normalized.

\section{RESULTS}

\section{Sediments}

Sediments were chiefly sandy in most of the ria (Table 1), and their distribution followed a gradient in grain size from the mouth towards the inner areas. Muddy bottoms were confined to inner and sheltered areas, and coarser sandy granulometric fractions were more frequent at the mouth of the ria. The gravel content $(0.1-52.7 \%)$ was 
TABLE 1. - Depth, physico-chemical characteristics of water and sediment and main biological features of sampling stations in the Ría de Aldán.

\begin{tabular}{|c|c|c|c|c|c|c|c|c|c|c|c|c|c|c|}
\hline Station & $\begin{array}{l}\text { Depth } \\
\text { (m) }\end{array}$ & $\begin{array}{l}\text { Sedimentary } \\
\text { type }\end{array}$ & $\begin{array}{l}\mathrm{Q}_{50} \\
(\mathrm{~mm})\end{array}$ & $\mathrm{S}_{0}$ & $\begin{array}{c}\text { Carbonates } \\
(\%)\end{array}$ & $\begin{array}{c}\text { TOM } \\
(\%)\end{array}$ & $\begin{array}{l}\mathrm{T}(\mathrm{sr}) \\
\left({ }^{\circ} \mathrm{C}\right)\end{array}$ & $\begin{array}{l}\mathrm{T}(\mathrm{bt}) \\
\left({ }^{\circ} \mathrm{C}\right)\end{array}$ & $\begin{array}{l}\mathrm{T}(\mathrm{sed}) \\
\quad\left({ }^{\circ} \mathrm{C}\right)\end{array}$ & $\mathrm{pH}($ sed $)$ & $\mathrm{S}$ & $\mathrm{N}$ & $\begin{array}{c}\mathrm{H}^{\prime} \\
\left(\log _{2}\right)\end{array}$ & $J^{\prime}$ \\
\hline 2 & 45 & Very coarse sand & 1.08 & Moderate & 73.9 & 2.6 & 21.1 & 22.9 & 20 & 7.63 & 81 & 1012 & 4.85 & 0.76 \\
\hline 3 & 36 & Very coarse sand & 1.98 & Moderate & 89.8 & 2.6 & 21.4 & 22.3 & 20.8 & 7.68 & 118 & 2749 & 3.93 & 0.57 \\
\hline 6 & 42 & Very coarse sand & 1.05 & Poor & 32.3 & 1.0 & 18.5 & 18.4 & 18.2 & 7.93 & 122 & 2011 & 4.95 & 0.71 \\
\hline 7 & 38 & Medium sand & 0.49 & Moderate & 67.4 & 1.4 & 17 & 17.7 & 17.4 & 5.75 & 108 & 2428 & 4.68 & 0.69 \\
\hline 8 & 25 & Fine sand & 0.21 & Mod. well sorted & 52.7 & 1.3 & 22.1 & 21.4 & 19.6 & 7.7 & 55 & 977 & 3.23 & 0.56 \\
\hline 9 & 12 & Fine sand & 0.20 & Mod. well sorted & 67.9 & 2.0 & 18.7 & 18.6 & 17.9 & 7.96 & 69 & 1099 & 4.11 & 0.67 \\
\hline 12 & 33 & Coarse sand & 0.87 & Moderate & 38.2 & 0.7 & 18.1 & 18.6 & 17.2 & 7.75 & 136 & 1434 & 5.69 & 0.80 \\
\hline 13 & 27 & Medium sand & 0.38 & Moderate & 40.8 & 1.1 & 16.8 & 16.7 & 16.6 & 7.69 & 77 & 1882 & 4.06 & 0.65 \\
\hline 14 & 10 & Medium sand & 0.39 & Moderate & 57.0 & 1.3 & 17.3 & 17.4 & 17 & 7.72 & 59 & 1718 & 3.88 & 0.66 \\
\hline 17 & 29 & Coarse sand & 0.62 & Moderate & 32.6 & 0.5 & 19.9 & 21.2 & 20.2 & 7.7 & 113 & 1006 & 5.55 & 0.81 \\
\hline 18 & 25 & Gravel & 2.22 & Moderate & 33.0 & 2.0 & 18.4 & 18.3 & 17.7 & 7.73 & 153 & 2298 & 5.77 & 0.79 \\
\hline 19 & 17 & Medium sand & 0.33 & Moderate & 64.1 & 1.7 & 18.4 & 18.1 & 17.1 & 7.95 & 108 & 1998 & 4.20 & 0.62 \\
\hline 20 & 15 & Medium sand & 0.30 & Moderate & 55.9 & 2.0 & 18.7 & 18.7 & 17.6 & 7.96 & 115 & 2097 & 5.20 & 0.76 \\
\hline 21 & 4 & Medium sand & 0.29 & Moderate & 70.0 & 3.1 & 21.1 & 20.8 & 20.2 & 7.94 & 68 & 3087 & 1.89 & 0.31 \\
\hline 22 & 13 & Fine sand & 0.19 & Mod. well sorted & 55.2 & 1.9 & 21.2 & 21.2 & 20.6 & 7.83 & 101 & 2054 & 4.44 & 0.67 \\
\hline 23 & 22 & Muddy sand & 0.20 & Mod. well sorted & 60.3 & 3.2 & 22.7 & 23.3 & 23 & 7.66 & 112 & 7228 & 3.11 & 0.46 \\
\hline 24 & 16 & Coarse sand & 0.92 & Moderate & 65.5 & 2.5 & 20.6 & 21.4 & 21.4 & 7.7 & 119 & 1562 & 4.33 & 0.63 \\
\hline 25 & 11 & Fine sand & 0.19 & Mod. well sorted & 54.2 & 1.6 & 21.2 & 21.5 & 21.6 & 7.88 & 82 & 1223 & 4.19 & 0.66 \\
\hline 26 & 8 & Fine sand & 0.14 & Moderate & 59.4 & 2.3 & 21.4 & 21.2 & 21.7 & 7.81 & 121 & 1336 & 5.68 & 0.82 \\
\hline 27 & 18 & Mud & 0.05 & Poor & 33.8 & 9.0 & 17.1 & 17.3 & 17.3 & 7.52 & 131 & 4789 & 4.35 & 0.62 \\
\hline 28 & 19 & Mud & 0.05 & Poor & 37.8 & 8.8 & 18.7 & 18.2 & 17.6 & 7.36 & 127 & 3692 & 3.98 & 0.57 \\
\hline 29 & 8 & Fine sand & 0.21 & Moderate & 59.9 & 2.2 & 17.9 & 18.2 & 18.2 & 7.71 & 130 & 2950 & 5.12 & 0.73 \\
\hline 30 & 3 & Coarse sand & 0.87 & Mod. well sorted & 41.9 & 0.7 & 21.6 & 21.5 & 23.5 & 7.92 & 108 & 9015 & 2.48 & 0.37 \\
\hline 31 & 17 & Mud & 0.04 & Moderate & 40.3 & 10.8 & 22.5 & 22.5 & 19.5 & 7.27 & 107 & 1965 & 3.73 & 0.55 \\
\hline 32 & 12 & Fine sand & 0.19 & Mod. well sorted & 63.0 & 1.5 & 17.5 & 18.7 & 18.4 & 7.68 & 134 & 1935 & 5.22 & 0.74 \\
\hline 33 & 4 & Muddy sand & 0.23 & Bad & 38.8 & 5.0 & 21 & 21.9 & 27.3 & 7.64 & 137 & 6044 & 4.60 & 0.65 \\
\hline 34 & 4 & Muddy sand & 0.31 & Poor & 33.5 & 1.1 & 21.3 & 22.9 & 21.2 & 7.56 & 127 & 12181 & 4.43 & 0.63 \\
\hline
\end{tabular}

$\mathrm{Q}_{50}$ : median grain size; $\mathrm{S}_{0}$ : sorting coefficient; TOM: total organic matter; $\mathrm{T}$ ( $\left.\mathrm{sr}\right)$ : surface water temperature; $\mathrm{T}$ (bt): bottom water temperature; T (sed): sediment temperature, S: number of species; N: total abundance per $0.28 \mathrm{~m}^{2}$; H': Shannon Wiener's diversity index; J': Pielou's evenness.

higher at stations 18 and $3(52.7$ and $47.9 \%$, respectively), while sandy fractions $(26.6-98.0 \%)$ recorded high values at stations 7, 8, 9 and $13(96.8-98.0 \%)$. The pelitic fractions showed the highest values at inner stations 27 , 28 and 31 (59.2-69.4\%), whereas the rest of the stations showed lower values, from $1.4 \%$ to $13.3 \%$. There was an increase in total organic matter content from the outer to the inner areas of the ria $(0.5-10.8 \%)$, whereas the calcium carbonate values were higher than $30 \%$ at all sampling stations (32.3-89.8\%). Stations 33 and 34 were also characterized by the presence of the seaweed Ulva spp. on the surface of the sediment.

\section{Benthic fauna}

Sampling yielded a total of 81770 specimens belonging to 496 species. Malacostracan crustaceans (162 species and 16851 individuals) and polychaetes (145 species and 28878 individuals) were the dominant groups in terms of number of species and individuals. Some taxa such as Nematoda, Nemertea and Harpacticoida were not identified to lower taxonomic levels.

Values of univariate measures are shown in Table 1. The lowest abundance values were recorded at station 8 (fine sand; 977 specimens), while the highest ones were recorded at station 34 (muddy sand; 12181 specimens). The number of species varied between 55 (St. 8) and 153 (St. 18). In general, total number of species increased towards the inner areas of the ria, showing the highest values at stations $27,28,29,32$,
33 and 34. The lowest number of species was recorded at the mouth of the ria, in the northeast area next to the shoreline (stations 8, 9 and 14). In number of species, polychaetes were the dominant group at 18 stations, while crustaceans dominated at 9 stations (mainly coastal stations with fine and medium sands). At station 34, polychaetes and molluscs showed a similar number of species.

In general, diversity $\left(\mathrm{H}^{\prime}\right)$ decreased from both the western and eastern margins of the mouth of the ria towards the central area. Maximum values were recorded at stations 17, 26, 12 and 18 (5.55-5.77). Minimum values were determined at stations 21,30 and 23 (1.89$3.11)$; this was due either to the low number of species present or because of the high numerical dominance

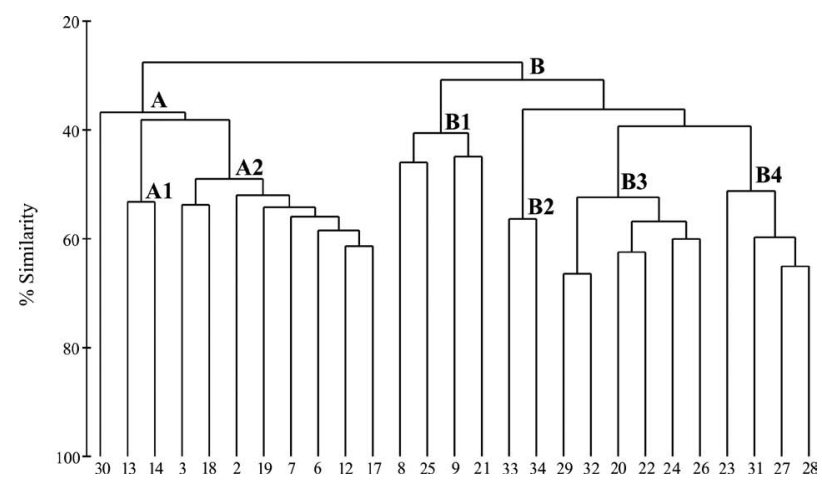

FIG. 2. - Faunal assemblages in the Ría de Aldán as determined by cluster analysis based on the Bray-Curtis similarity coefficient. 
of any given species. Evenness showed low values on sediments with a high dominance of the amphipod Siphonoecetes kroyeranus (St. 21), nematodes (St. 30) and the polychaete Paradoneis lyra (St. 23 and 31).

The polychaetes Paradoneis lyra and Spio decoratus, the crustaceans Myodocopida sp. 3, Apseudes latreillii, Siphonoecetes kroyeranus, Photis longipes and
Gammarella fucicola, the molluscs Caecum trachea and Mysella bidentata, and Nematoda spp. accounted for $50 \%$ of all the fauna.

The most widespread taxa in the ria, apart from the suprageneric taxa Nematoda spp., Nemertea spp. and Harpacticoida spp., were Thracia papyracea (found at 24 stations), Spio decoratus, Heteromastus filiformis (23

TABLE 2. - Summary of abiotic and biotic characteristics for each assemblage defined by multivariate analyses. TOM: total organic matter; S: number of species; N: total abundance per $0.28 \mathrm{~m}^{2} ; \mathrm{H}^{\prime}$ : Shannon Wiener's diversity index; J': Pielou's evenness.

\begin{tabular}{|c|c|c|c|c|c|c|c|}
\hline & & A1 & A2 & B1 & B2 & B3 & B4 \\
\hline $\mathrm{Q}_{50}(\mathrm{~mm})$ & & $0.38-0.39$ & $0.33-2.22$ & $0.19-0.29$ & $0.23-0.31$ & $0.14-0.92$ & $0.04-0.2$ \\
\hline Depth (m) & & $10-27$ & $17-45$ & $4-25$ & 4 & $8-16$ & $17-22$ \\
\hline \multirow[t]{2}{*}{ Carbonates $(\%)$} & Range & $40.77-56.96$ & $32.33-89.84$ & $52.75-69.98$ & $33.51-38.81$ & $55.17-65.48$ & $33.85-60.32$ \\
\hline & Mean \pm SD & $48.86 \pm 11.45$ & $53.92 \pm 22.63$ & $61.20 \pm 8.98$ & $36.19 \pm 3.74$ & $59.82 \pm 3.99$ & $43.07 \pm 11.8$ \\
\hline \multirow[t]{2}{*}{ TOM (\%) } & Range & $1.12-1.33$ & $0.47-2.60$ & $1.25-3.08$ & $1.08-4.97$ & $1.47-2.50$ & $3.17-10.8$ \\
\hline & Mean \pm SD & $1.23 \pm 0.15$ & $1.56 \pm 0.81$ & $1.98 \pm 0.8$ & $3.03 \pm 2.75$ & $2.08 \pm 0.36$ & $7.95 \pm 3.31$ \\
\hline \multirow[t]{2}{*}{$\mathrm{S}$} & Range & $59-77$ & $81-153$ & $55-82$ & $127-137$ & $101-134$ & $107-131$ \\
\hline & Mean \pm SD & $68 \pm 12.73$ & $117.38 \pm 21.23$ & $68.5 \pm 11.03$ & $132 \pm 7.07$ & $120 \pm 11.7$ & $119.25 \pm 11.56$ \\
\hline \multirow[t]{2}{*}{$\mathrm{N}$} & Range & $1718-1882$ & $1006-2749$ & $977-3087$ & 6044-12181 & $1336-2950$ & $1965-7228$ \\
\hline & Mean $\pm S D$ & $1800 \pm 115.97$ & $1867 \pm 652.04$ & $1596.5 \pm 998.73$ & $9112.5 \pm 4339.51$ & $1989 \pm 556.97$ & $4418.5 \pm 2204.39$ \\
\hline \multirow{2}{*}{$H^{\prime}\left(\log _{2}\right)$} & Range & $3.88-4.06$ & $3.93-5.77$ & $1.89-4.19$ & $4.43-4.60$ & $4.33-5.68$ & $3.11-4.35$ \\
\hline & Mean \pm SD & $3.97 \pm 0.13$ & 4.950 .68 & $3.35 \pm 1.07$ & $4.51 \pm 0.12$ & $5 \pm 0.52$ & $3.79 \pm 0.52$ \\
\hline \multirow[t]{2}{*}{$\mathrm{J}^{\prime}$} & Range & $0.65-0.66$ & $0.57-0.81$ & $0.31-0.67$ & $0.65-0.63$ & $0.63-0.82$ & $0.46-0.62$ \\
\hline & Mean $\pm S D$ & $0.65 \pm 0.01$ & 0.720 .09 & $0.55 \pm 0.17$ & $0.64 \pm 0.01$ & $0.72 \pm 0.07$ & $0.55 \pm 0.07$ \\
\hline
\end{tabular}

TABLE 3. - The first ten species according to frequency $\mathrm{x}$ dominance values of each group of stations.

\begin{tabular}{|c|c|c|c|c|c|c|c|}
\hline & Code & A1 & A2 & B1 & B2 & B3 & B4 \\
\hline Nematoda spp. & Nem spp & 2091.25 & 1560.69 & 2062.42 & 963.60 & 557.65 & 597.46 \\
\hline Pisione parapari & Pis par & 1733.70 & 192.91 & & & & \\
\hline Spio decoratus & Spi dec & 1304.99 & & 873.18 & & 477.99 & \\
\hline Streptosyllis websteri & Str web & 672.11 & & & & & \\
\hline Thracia papyracea & Thr pap & 351.84 & & 548.41 & & 578 & \\
\hline Pisione remota & Pis rem & 327.98 & 209.04 & & & & \\
\hline Nephtys cirrosa & Nep cir & 197.25 & & 204.35 & & & \\
\hline Caecum trachea & Cae tra & 197.24 & 480.66 & & & & \\
\hline Polygordius lacteus & Pol lac & 189.91 & 391.62 & & & & \\
\hline Nemertea spp. & & 178.91 & & & & & \\
\hline Protodorvillea kefersteini & Pro kef & & 569.17 & & & & \\
\hline Goodallia triangularis & Goo tri & & 322.86 & & & & \\
\hline Heteromastus filiformis & Het fil & & 298.91 & & & & \\
\hline Parapionosyllis minuta & Par min & & 284.10 & & & & \\
\hline Caulleriella bioculata & Cau bio & & 200.86 & & 303.83 & & \\
\hline Siphonoecetes kroyeranus & Sip kro & & & 2028.08 & & & \\
\hline Pontocythere sp. & Pon sp & & & 410.17 & & & \\
\hline Diogenes pugilator & Dio pug & & & 290.59 & & & \\
\hline Perioculodes longimanus & Per lon & & & 97.42 & & 202.78 & \\
\hline Harpacticoida spp. & Har spp & & & 82.75 & & & \\
\hline Nassarius reticulatus & & & & 75.36 & & & \\
\hline Myodocopida sp. 3 & Myo sp3 & & & & 1330.82 & & \\
\hline Gammarella fucicola & Gam fuc & & & & 1288.56 & & \\
\hline Photis longipes & Pho lon & & & & 506.21 & 549.40 & \\
\hline Pholoe synophthalmica & & & & & 287.47 & & \\
\hline Parvicardium exiguum & & & & & 284.42 & & \\
\hline Syllis garciai & Syl gar & & & & 217.94 & & \\
\hline Mysella bidentata & Mys bid & & & & 165.95 & 292.27 & 884.87 \\
\hline Ampithoe ramondi & & & & & 143.10 & & \\
\hline Apseudes latreillii & Aps lat & & & & & 1345.68 & \\
\hline Paradoneis armata & Par arm & & & & & 443.73 & \\
\hline Chaetozone gibber & Cha gib & & & & & 224.37 & \\
\hline Chamelea striatula & Cha str & & & & & 211.46 & \\
\hline Paradoneis lyra & Par lyr & & & & & & 4003.67 \\
\hline Prionospio pulchra & Pri pul & & & & & & 607.14 \\
\hline Thyasira flexuosa & Thy fle & & & & & & 455.84 \\
\hline Abra alba & Abr alb & & & & & & 246.22 \\
\hline Ampharete finmarchica & & & & & & & 217.26 \\
\hline Amphiura chiajei & & & & & & & 140.24 \\
\hline Euclymene oerstedii & & & & & & & 130.35 \\
\hline Exogone hebes & & & & & & & 120.85 \\
\hline
\end{tabular}


stations each), and Nephtys cirrosa, Leucothoe incisa, Tellina donacina and Dosinia exoleta (22 stations each).

\section{Multivariate analysis}

The dendrogram obtained by cluster analysis showed the presence of two major groups of stations at a similarity level of $30 \%$ (Fig. 2). Group A was further subdivided into group A1 (medium-sand) and group A2 (coarse sand) at a similarity level of $40 \%$. Group B was subdivided into B1 (fine-sand stations close to the shoreline), B2 (muddy sand), B3 (fine sand) and B4 (mud) at a similarity level of $40 \%$. nMDS ordination showed similar results to those of the dendrogram (stress: 0.13). The summary of characteristics for each association is shown in Table 2 and the first ten species according to frequency $\mathrm{x}$ dominance values of each group of stations are shown in Table 3.

Group A was located in the outer part of the ria. The species which mostly contributed to characterizing group A1 (medium sand) were Spio decoratus, Pisione parapari, Streptosyllis websteri, Pisione remota, Nephtys cirrosa, Caecum trachea, Polygordius lacteus, Thracia papyracea and Nemertea spp. Group A2 (coarse sand) was characterized by several polychaete species, such as Polygordius lacteus, Pisione parapari, Pisione remota, Parapionosyllis minuta, Heteromastus filiformis, Caulleriella bioculata and Protodorvillea

TABLE 4. - Results of SIMPER analysis. Species were ranked according to their average contributions to dissimilarity (AD) between assemblages in the Ría de Aldán. Average abundance (AA), ratio value (R: dissimilarity/standard deviation) and percentage of cumulative dissimilarity (\% Cum) were also included.

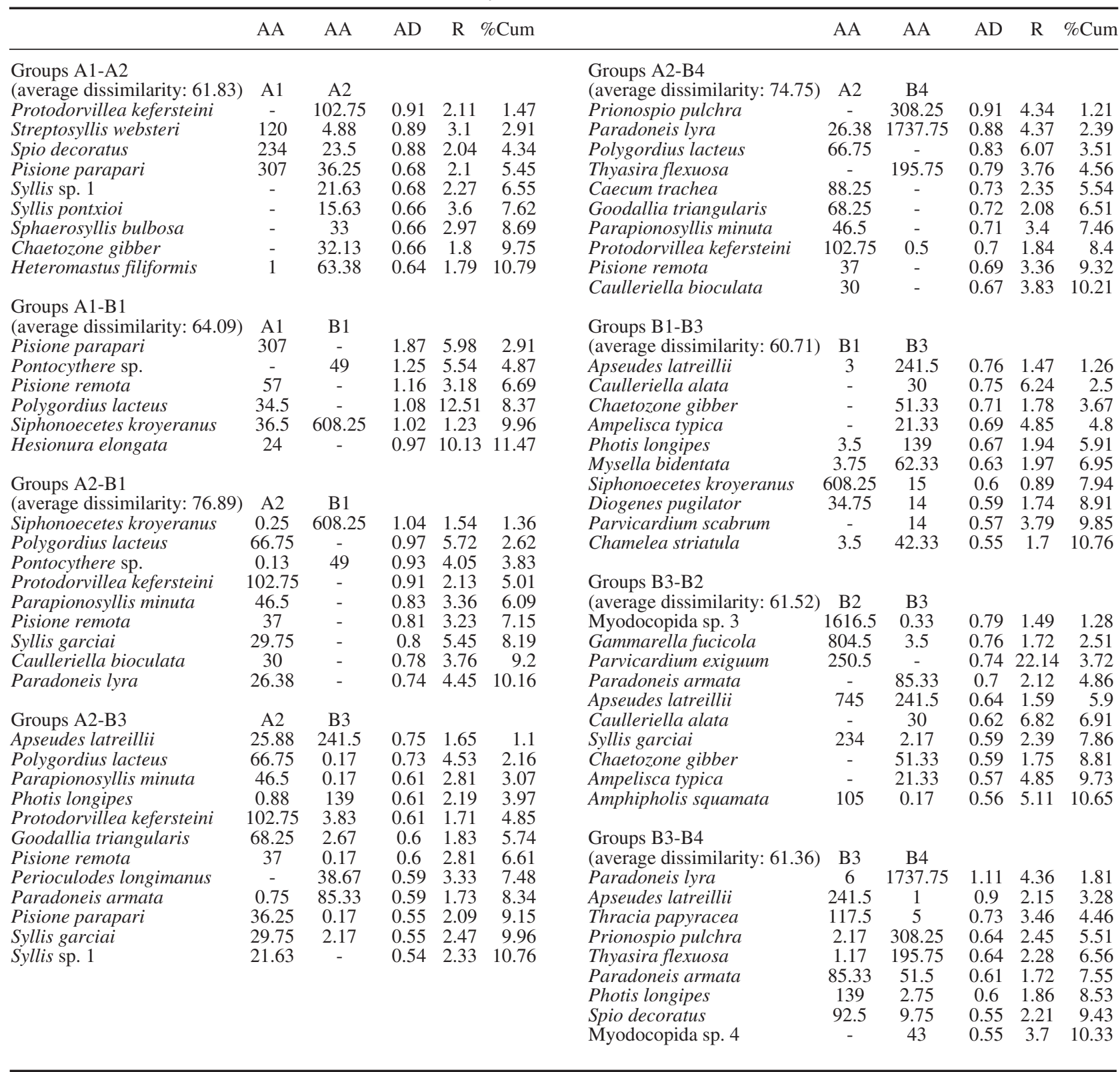


kefersteini, and the molluscs Caecum trachea and Goodallia triangularis. Group B was located in the sheltered area of the ria. The species that most contributed to similarities in B1 were Pontocythere sp., Nephtys cirrosa, Siphonoecetes kroyeranus, Thracia papyracea, Spio decoratus, Diogenes pugilator, Perioculodes longimanus, Harpacticoida spp. and Nassarius reticulatus. Group B2 (muddy sand) was characterized by Caulleriella bioculata, Syllis garciai, Myodocopida sp. 3, Gammarella fucicola, Photis longipes, Pholoe synophthalmica, Parvicardium exiguum, Mysella bidentata and Ampithoe ramondi, while Group B3 (fine sand) was characterized by Thracia papyracea, Spio decoratus, Apseudes latreillii, Mysella bidentata, Photis longipes, Perioculodes longimanus, Paradoneis armata, Chaetozone gibber and Chamelea striatula. The species which most contributed to characterizing group B4 (mud) were Paradoneis lyra, Mysella bidentata, Prionospio pulchra, Ampharete finmarchica, Abra alba, Amphiura chiajei, Euclymene oerstedii, Exogone hebes and Thyasira flexuosa.

SIMPER analysis (Table 4) showed that Protodorvillea kefersteini, Streptosyllis websteri, Spio decoratus and Pisione parapari explained most of the dissimilarity between groups A1 and A2. Pisione parapari, Pontocythere sp. and Pisione remota contributed greatly to the differentiation of A1 from B1. Siphonoecetes kroyeranus and Polygordius lacteus differentiated group A2 from B1. Group A2 differed from B3 due to Apseudes latreillii and Polygordius lacteus. Prionospio pulchra and Paradoneis lyra differentiated group A2 from B4, whereas Apseudes latreillii and Caulleriella alata differentiated group B1 from B3. Myodocopida sp. 3, Gammarella fucicola and Parvicardium exiguum explained most of the dissimilarity between groups B2 and B3, while Paradoneis lyra and Apseudes latreillii greatly contributed to separating B3 from B4.

\section{Species affinities}

Cluster analysis done on the abundance data of the dominant species showed the existence of five major groups at the similarity level of $30 \%$ (Fig. 3). Group 1 comprised species mostly found in gravel, group 2 comprised species found in muddy sands (cluster group B2), while group 3 comprised species with higher abundance in mud (cluster group B4). Group 4 was composed of nine species mostly found in coarse sand (cluster group A), and three species mostly found in muddy sand. Finally, group 5 was subdivided into group 5a (fine-sand species), 5b (a number species found in several types of sediment) and $5 \mathrm{c}$ (species found in fine and muddy sands).

\section{Relation of benthic fauna with environmental variables}

The BIO-ENV procedure showed that the combination of gravel, coarse sand, fine sand, very fine sand,

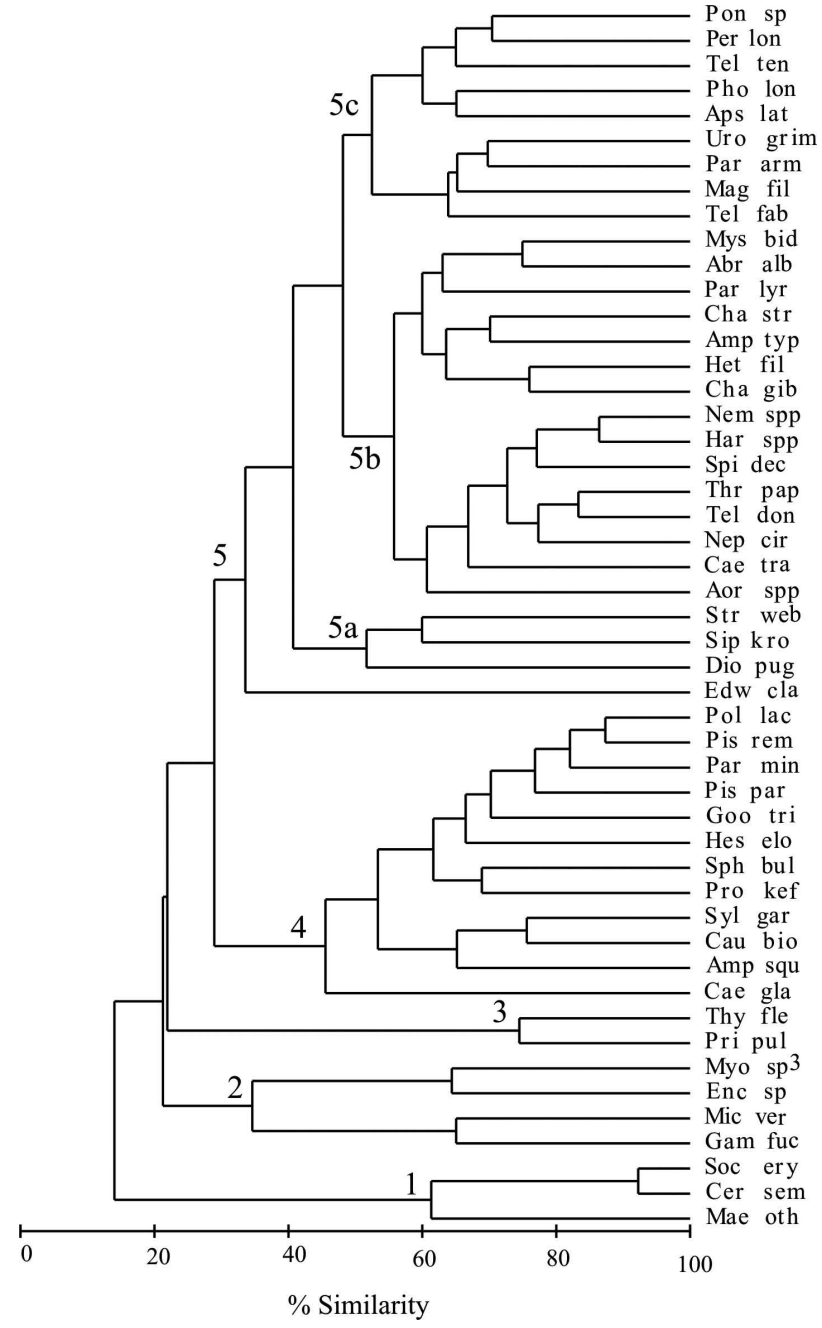

FIG. 3. - Dendrogram based on cluster analysis showing the classification of species with a numerical dominance $\geq 4 \%$ at any given site. Species codes are given in Table 3, except: Ampelisca typica: Amp typ; Amphipholis squamata: Amp squ; Aoridae spp: Aor spp; Caecum glabrum: Cae gla; Ceradocus semiserratus: Cer sem; Edwarsia claparedii: Edw cla; Enchytraeida sp.: Enc sp; Maera othonis: Mae oth; Magelona filiformis: Mag fil; Microdeutopus versiculatus: Mic ver; Socarnes erythrophthalmus: Soc ery; Sphaerosyllis bulbosa: Sph bul; Tellina donacina: Tel don; Tellina fabula: Tel fab; Tellina tenuis: Tel ten; Urothoe grimaldii: Uro grim.

depth, redox potential (Eh) and total organic matter content had the highest correlation with faunistic data $\left(\rho_{\mathrm{w}}: 0.615\right)$. Very fine sand was the variable that alone showed the highest correlation with the faunistic data $\left(\rho_{\mathrm{w}}: 0.462\right)$.

Axes I and II of the forward selection of CCA were the most important in the CCA ordination, accumulating $24.1 \%$ of species variance and $31.1 \%$ of speciesenvironment variance. Cluster groups with higher content of coarser granulometric fractions were distributed on the left of the ordination, while assemblages distributed along fine-sand and muddy sediments were distributed on the right, following a gradient defined by a decrease in median grain size (Fig. 4). 


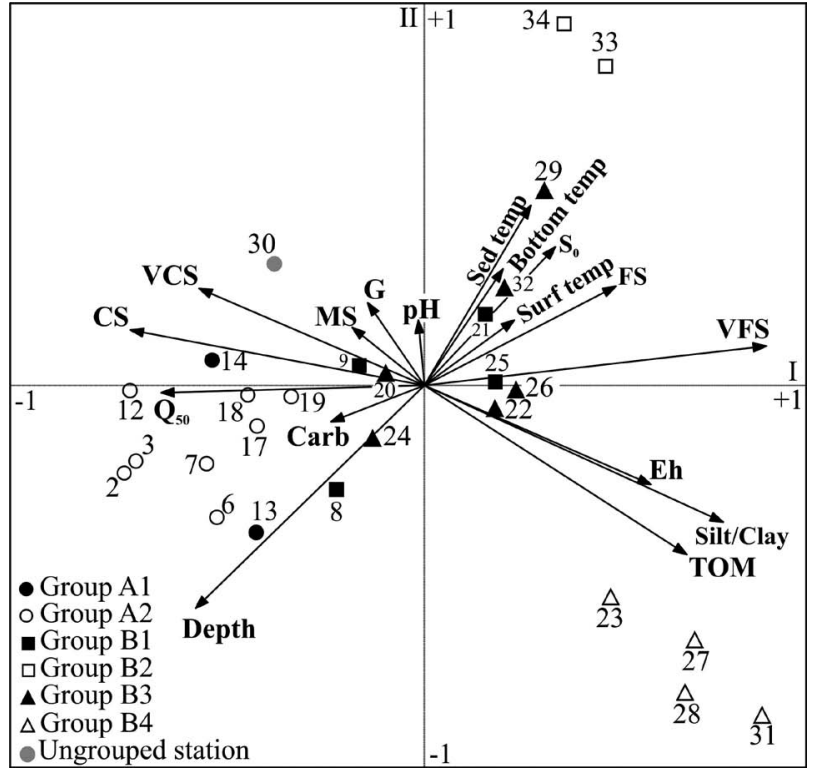

FIG. 4. - Canonical correspondence analysis (CCA) ordination of stations and environmental variables relative to axes I and II for the Ría de Aldán. Gravel, G; very coarse sand, VCS; coarse sand, CS; medium sand, MS; fine sand, FS; very fine sand, VFS; median grain size, $\mathrm{Q}_{50}$; sorting coefficient, $\mathrm{S}_{0}$; bottom temperature, Bottom temp; sea surface temperature, Surf temp; sediment temperature, Sed temp; carbonate content, Carb; total organic matter content, TOM.

\section{DISCUSSION}

This study shows that the Ría de Aldán has a diverse soft-bottom benthic fauna. In total, 496 different taxa were found in a variety of sediments ranging from very coarse sand to mud. The multivariate analyses revealed the presence of several benthic assemblages whose distribution along the ria is related to that of sediment types. In addition, the faunistic composition of the assemblages mostly agrees with those of several communities or facies, as described by Petersen (1918) or Thorson (1957). Thus, the assemblage of group A2 of cluster can be included among the different varieties of the Branchiostoma lanceolatum-Venus fasciata community (Thorson, 1957) present on clean coarse sediments with a high content of biogenic carbonates (Table 5). The medium-sand assemblage corresponding to group A1 showed intermediate features between the Venus fasciata community and the Venus gallina community (fine sand); this group has a low number of exclusive species (3), suggesting that these sites are a transition zone between different assemblages, i.e. the coarse-sand assemblage (group A2) and the fine-muddy sand assemblage (group B). The fine-sand sites of group B1 are characterized by species which are typical of the Venus gallina community (Thorson, 1957). The muddy sands of group B2 are located in the inner ria, into which the Aldán River flows; this group is characterized by the presence of seaweeds (Ulva spp.) that may favour the appearance of epifaunal species such as Bittium reticulatum. Group B3 (the fine-sand assemblage) shows similarities with the Venus gallina community described by Thorson (1957); coastal and shallow sites also have typical species from the Tellina tenuis-Tellina fabula community (Thorson, 1957). Group B4 is characterized by muddy sediments showing the highest content of organic matter in the ria. The species found there are characteristic of the Syndosmya alba community and the Amphiura community. In general, the distribution of assemblages and sediments is similar to that found in other Galician rias with similar orientation and exposure to oceanic swell such as the Ría da Coruña (López-Jamar and Mejuto, 1985), the Ría de Ares-Betanzos (Garmendia et al., 1998) and the Ensenada de Baiona (Moreira and Troncoso, 2008).

Soft bottom faunas are often structured by abiotic factors (Labrune et al., 2008). Several studies have highlighted sedimentary features among the most important factors influencing the composition and distribution of benthic assemblages in marine sediments (e.g. Pearson and Rosenberg, 1978). In the Ría de Aldán, there is a correlation between the spatial distribution of the benthic fauna and the granulometric composition of the sediment. Thus, there is a conspicuous grain-size gradient in the study area, which is defined by an increase in finer sandy fractions from the mouth of the ria towards the inner margins. When studied separately, the distribution of the molluscan, polychaete and peracarid assemblages in the Ría de Aldán also follows this sedimentary gradient (Lourido et al., 2006, 2008a,b). Although hydrodynamic features of the Ría de Aldán were not measured, hydrodynamism is known to act as a "superparameter" which has a major influence on sedimentation of particles and organic matter, stability of sediments and patterns of sedimentary distribution, and therefore on faunal composition (Rosenberg, 1995). In general, the particular overall granulometric composition of the sediments in the Galician rias is a consequence of the hydrodynamic regime found there (López-Jamar, 1981). Thus, the greater hydrodynamism due to exposure to oceanic swell in the outer areas of the rias does not allow deposition of finer particles and results in the presence of coarser sediments (Troncoso et al., 1993); finer sediments occurs in sheltered, inner areas of low energy. The effects of hydrodynamism thus result in a gradation of sediment grain size along the rias, which translates into a presence of assemblages typical of coarse sediment in the outer areas and those of fine sand or mud in the inner areas. Those patterns can be altered by the construction of artificial structures on the shoreline, which results in changes in current dynamics (López-Jamar and Mejuto, 1985), or by the deposition on the sediment of large amounts of pseudofaeces produced by mussels cultured on rafts (Abella et al., 1996).

The total number of species has been used to describe biodiversity in many studies (Olsgard et al., 2003) and therefore will be used here as a simple measure to establish comparisons in benthic diversity among different areas. In general, the total number of species found on the subtidal soft bottoms of the Ría 
TABLE 5. - Characteristic species of the benthic assemblages of the Ría de Aldán determined by multivariate analyses; other assemblages in which those species were previously reported are also indicated. 1, Venus fasciata community (Glémarec, 1973); 2, Assemblage of Goniadella-Spisula (Salzwedel et al., 1985); 3, Branchiostoma lanceolatum of gravel and sandy gravel facies (Toulemont, 1972); 4, Gravel and coarse sand assemblage (Troncoso and Urgorri, 1993); 5, Coarse-sand sediments (Besteiro et al., 1987); 6, Facies of Zostera noltii (Olabarria et al., 1998); 7, Syndosmya alba community (Petersen, 1918); 8, Other facies from Syndosmya alba community; 9, Heterogeneous sandy gravels and heterogeneous muddy sands (Chassé and Glémarec, 1976); 10, Boreo-mediterranean Amphiura community (Petersen, 1918); 11, Maldane glebifex-Amphiura filiformis-Amphiura chiajei subcommunity (Toulemont, 1972); 12, Mud assemblage (Moreira et al., 2006).

\begin{tabular}{|c|c|c|c|c|c|}
\hline Species & $\begin{array}{c}\text { Characteristic } \\
\text { species }\end{array}$ & $\begin{array}{c}\text { Facies/ } \\
\text { Community }\end{array}$ & Species & $\begin{array}{c}\text { Characteristic } \\
\text { species }\end{array}$ & $\begin{array}{c}\text { Facies/ } \\
\text { Community }\end{array}$ \\
\hline Goodallia triangularis & A1 & 4 & Myodocopida sp. 3 & B2 & \\
\hline Pisione remota & A1 & 2 & Gammarella fucicola & B2 & \\
\hline Streptosyllis websteri & A1 & & Parvicardium exiguum & B2 & \\
\hline Spio decoratus & A1 & & Apseudes latreillii & B2, B3 & \\
\hline Pisione parapari & A1 & & Photis longipes & $\mathrm{B} 2, \mathrm{~B} 3$ & \\
\hline Lepidepecreum longicornis & A1 & & Mysella bidentata & $\mathrm{B} 2, \mathrm{~B} 4$ & \\
\hline Atylus falcatus & $\mathrm{A} 1$ & & Spisula elliptica & B3 & \\
\hline Gastrosaccus spinifer & A1 & 1 & Tellina fabula & B3 & \\
\hline Nephtys cirrosa & $\mathrm{A} 1, \mathrm{~A} 2, \mathrm{~B} 1, \mathrm{~B} 3$ & 1,2 & Echinocardium cordatum & B3 & \\
\hline Caecum trachea & $\mathrm{A} 1, \mathrm{~A} 2, \mathrm{~B} 2$ & 4 & Tellina tenuis & B3 & \\
\hline Thracia papyracea & $\mathrm{A} 1, \mathrm{~B} 1, \mathrm{~B} 3$ & & Magelona filiformis & B3 & \\
\hline Protodorvillea kefersteini & $\mathrm{A} 2$ & 5 & Chamelea striatula & B3 & \\
\hline Polygordius lacteus & A2 & $1,3,5$ & Abra alba & B4 & $7,8,9,11$ \\
\hline Caecum glabrum & A2 & & Corbula gibba & B4 & 7,9 \\
\hline Branchiostoma lanceolatum & $\mathrm{A} 2$ & 1 & Lagis koreni & B4 & $7,8,11$ \\
\hline Echinocyamus pusillus & $\mathrm{A} 2$ & 1 & Nucula nitidosa & B4 & 7,10 \\
\hline Clausinella fasciata & A2 & 4 & Abra nitida & B4 & $8,10,11$ \\
\hline Gari tellinella & A2 & 1,3 & Euclymene oerstedii & B4 & 8 \\
\hline Arcopagia crassa & A2 & 1,4 & Melinna palmata & B4 & 8,11 \\
\hline Ampelisca spinipes & $\mathrm{A} 2$ & 3 & Pherusa eruca & B4 & 9 \\
\hline Glycera lapidum & $\mathrm{A} 2$ & 3,4 & Terebellides stroemi & B4 & $9,10,11$ \\
\hline Timoclea ovata & A2 & 3 & Thyone fusus & B4 & 9 \\
\hline Digitaria digitaria & A2 & 4 & Turritella communis & B4 & 9 \\
\hline Tellina donacina & A2 & 4 & Amphiura chiajei & B4 & 10 \\
\hline Retusa mammillata & A2 & 4 & Aporrhais pespelecan & B4 & 10 \\
\hline Microjaera anisopoda & $\mathrm{A} 2$ & 5 & Myrtea spinifera & B4 & 11 \\
\hline Siphonoecetes kroyeranus & B1 & & Cossura pygodactylata & B4 & 12 \\
\hline Nassarius reticulatus & B1 & & Podarkeopsis capensis & B4 & 12 \\
\hline Perioculodes longimanus & B1, B3 & & Exogone hebes & B4 & 12 \\
\hline Venerupis senegalensis & B2 & 6 & Prionospio fallax & B4 & 12 \\
\hline Bittium reticulatum & B2 & 6 & Paradoneis lyra & B4 & \\
\hline Loripes lacteus & $\mathrm{B} 2$ & 6 & Prionospio pulchra & B4 & \\
\hline Lucinoma borealis & B2 & & Thyasira flexиosa & B4 & 8,10 \\
\hline
\end{tabular}

de Aldán (496) was high taking into account the spatial scale of sampling $(<10 \mathrm{~km})$ and in comparison with other Galician rias and with estuaries, fjords and bays across the European Atlantic (see Table 6). However, accurate comparisons among different geographic areas according to total number of species and other biological parameters are limited by differences in local physical conditions, taxonomic knowledge, sampling procedures (e.g. mesh size, sampling gear, sample size) and time of the year of sampling (De Grave et al., 2001). The benthic biodiversity of the Ría de Aldán mostly agrees with that reported from other similar Galician rias, such as the Ría de Ares-Betanzos and the Ensenada de Baiona. This high biodiversity might be related to the variety of sediments present in these rias, ranging from gravel to mud. In short, this sedimentary heterogeneity provides a large variety of ecological niches across a small spatial scale, thus supporting a greater diversity of species than more homogenous sediments do (Pearson and Rosenberg, 1978). In addition, the high primary production related to upwelling events occurring in the rias usually twice a year (Figueiras et al., 2002) might grant a priori an important food supply for the benthic fauna which, in turn, might benefit the presence of richer faunas there than in other areas. On the contrary, previous work done in other Galician rias of similar or greater size (e.g. Ría de Vigo, Ría de Pontevedra) shows that these have a smaller number of species (Mora et al., 1982; LópezJamar and Cal, 1990). This fact might be related to the greater sedimentary homogeneity found there, with a predominance of the silt/clay fractions; the greater presence of mud is greatly related to anthropogenic alterations such as those reported above.

In conclusion, the subtidal sediments of the Ría de Aldán show a rich benthic fauna whose diversity and distribution is linked to the hydrodynamic and sedimentary features, as occurs in other Galician rias. The overall situation suggests that most of the benthic environment of the Ría de Aldán has not yet been greatly altered by phenomena of organic enrichment in spite of the presence of a number of rafts devoted to mussel culture in the central part of the ria. Nevertheless, our results emphasize, again, the need for baseline studies to obtain a basic knowledge of the environment in order to develop proper short- and long-term strategies for conservation that will avoid impoverishment of benthic assemblages and loss of biodiversity. 
TABLE 6. - Comparison of total number of species (N) of macrobenthic fauna in the Ría de Aldán and that in other European areas. Main physical features of sampling areas and sampling methodology are also indicated for bibliographic references.

\begin{tabular}{|c|c|c|c|c|c|c|c|}
\hline Geographic area & $\mathrm{N}$ & $\begin{array}{c}\text { Spatial sca } \\
\quad(\mathrm{km})\end{array}$ & $\begin{array}{l}\text { ale Depth } \\
\text { (range, m) }\end{array}$ & $\begin{array}{c}\text { Substrata } \\
\text { (range) }\end{array}$ & $\begin{array}{c}\text { Sampling } \\
\text { stations }\end{array}$ & $\begin{array}{c}\text { Mesh size } \\
(\mathrm{mm})\end{array}$ & $\begin{array}{l}\text { Sampling } \\
\text { gear }\end{array}$ \\
\hline \multicolumn{8}{|l|}{ Galicia (NW Spain) } \\
\hline Ría de Aldán (this work) & 496 & $<10$ & $3-45$ & VCS-M & 27 & 0.5 & $\mathrm{VV}$ \\
\hline Ensenada de Baiona (Moreira and Troncoso, 2008) & 474 & $<10$ & $2-12$ & GR-M & 21 & 0.5 & VV \\
\hline Ensenada de San Simón (Cacabelos et al., 2008) & 362 & $<10$ & $1-28$ & VCS-M & 29 & 0.5 & VV \\
\hline Ría de Vigo (López-Jamar and Cal, 1990) & 137 & 25 & $10-35$ & S-M & 21 & 0.5 & $\mathrm{BC}$ \\
\hline Ría de Pontevedra (Mora et al., 1982) & 229 & 20 & $0-40$ & CS-M & 32 & N/A & $\mathrm{VV}, \mathrm{RB}$ \\
\hline Ría de Arousa (López-Jamar, 1982) & 110 & 15 & $10-40$ & S-M & 13 & 0.5 & VV \\
\hline Ría de Muros (López-Jamar, 1981) & 109 & 10 & $15-45$ & $\mathrm{~S}-\mathrm{M}$ & 13 & 0.5 & VV \\
\hline Ría de Coruña (López-Jamar and Mejuto, 1985) & 129 & $<10$ & $8-33$ & CS-M & 26 & 0.5 & $\mathrm{BC}$ \\
\hline Ría de Ares-Betanzos (Garmendia et al., 1998) & 426 & 12 & $2-44$ & GR-SM & 53 & $1.0,0.5$ & $\mathrm{BC}, \mathrm{RB}$ \\
\hline \multicolumn{8}{|l|}{ Iberian Peninsula (excluding Galicia) } \\
\hline Bahía de Santander (Lastra et al., 1990) & 197 & $<10$ & $0-21$ & MS-M & 45 & 1.0 & VV \\
\hline Sado Estuary (Carvalho et al., 2001) & 151 & $<10$ & $5-20$ & CS-M & 31 & 1.0 & SM \\
\hline Albufeira Lagoon (Quintino et al., 1987) & 126 & $<10$ & $0-15$ & CS-M & 50 & 1.0 & $\mathrm{PO}, \mathrm{RB}$ \\
\hline \multicolumn{8}{|l|}{ European Atlantic } \\
\hline Oslofjord, Norway (Mirza and Gray, 1981) & 146 & 35 & $0-160$ & M & 76 & 1.0 & TD \\
\hline Olderfjord, Lafjord, Byluft Bay (Holte et al., 2004) & 399 & $<10$ & $10-90$ & S-M & 13 & 1.0 & VV \\
\hline Arcachon Bay (Bachelet et al., 1996) & 141 & 20 & $2-18$ & GR-M & 18 & 1.0 & SM, SH, EK \\
\hline Marennes-Oléron Bay (Montaudouin and Sauriau, 2000) & 332 & 25 & $0-15$ & N/A & 262 & $1.0 \mathrm{~S}$ & SM, manual corers \\
\hline \multicolumn{8}{|l|}{ Mediterranean } \\
\hline Mar Grande, Mar Piccolo (Mastrototaro et al., 2008) & 131 & 10 & $5-35$ & SM-M & 47 & N/A & VV \\
\hline Argolikos Bay (Makra and Nicolaidou, 2000) & 151 & $<10 \mathrm{~km}$ & $5-10$ & S-M & 7 & 1.0 & $\mathrm{PO}$ \\
\hline
\end{tabular}

GR, gravel; VCS, very coarse sand; CS, coarse sand; MS, medium sand; S, sand; SM, sandy mud; M, mud. BC, Box Corer; EK, Ekman grab; PO, Ponar grab; Rallier du Baty. SH, Shipek grab; SM, Smith-McIntyre grab; TD, Triangular dredge; VV, Van Veen grab.

\section{ACKNOWLEDGEMENTS}

The authors wish to express their gratitude to their laboratory colleagues for their invaluable help with many tasks, including sample collection, and to Dr Jean Claude Sorbe (Station Marine d'Arcachon) for his help in identying the peracarid taxa. Two anonymous referees and the editor provided valuable suggestions which greatly improved the manuscript. This study was part of a PhD (A.L.) supported by a FPU scholarship of the Spanish Ministry of Education and Science Ministry.

\section{REFERENCES}

Abella, F.E., J.M. Parada and J. Mora. - 1996. Relationship between the macrobenthic community structure and the presence of mussel rafts culture in the Ria de Vigo (NW Iberian Peninsula). Crangon, 1: 111-118.

Bachelet, G., X. de Montaudouin and J.-C. Dauvin. - 1996. The quantitative distribution of subtidal macrozoobenthic assemblages in Arcachon Bay in relation to environmental factors: a multivariate analysis. Est. Coast. Shelf Sci., 42: 371-391.

Besteiro, C., V. Urgorri and J. Parapar. - 1987. Aportaciones nuevas para la fauna ibérica: Anélidos Poliquetos. Cah. Biol. Mar., 28: 491-504.

Cacabelos, E., L. Gestoso and J.S. Troncoso. - 2008. Macrobenthic fauna in the Ensenada de San Simón (Galicia, north-western Spain). J. Mar. Biol. Ass. UK., 88(2): 237-245.

Carvalho, S., A. Ravara, V. Quintino and A.M. Rodrigues. - 2001. Macrobenthic community characterisation of an estuary from the western coast of Portugal (Sado estuary) prior to dredging operations. Bol. Inst. Esp. Oceanogr., 17(1-2): 179-190.

Chassé, C. and M. Glémarec. - 1976. Principes généraux de la classification des fonds pour la cartographie biosédimentaire. $J$. Res. Oceanogr., 1(3): 1-18.
Clarke, K.R. and R.M. Warwick. - 1994. Change in marine communities: an approach to statistical analysis and interpretation. Natural Environmental Research Council, UK.

De Grave, S., D. Casey and A. Whitaker. - 2001. The accuracy of density standardization of infaunal benthos. J. Mar. Biol. Ass. U.K., 81: 541-542.

Ellis, J.I., A. Norkko and S.F. Trush. - 2000. Broad-scale disturbance of intertidal and shallow sublittoral soft-sediment habitats; effects on the benthic macrofauna. J. Aquat. Ecosyst. Stress Recov., 7: 57-74.

Field, J.G., K.R. Clarke and R.M. Warwick. - 1982. A practical strategy for analysing multispecies distribution patterns. Mar. Ecol. Prog. Ser., 8: 37-52.

Figueiras, F.G., U. Labarta and M.J. Fernández. - 2002. Coastal upwelling, primary production and mussel growth in the Rias Baixas of Galicia. Hydrobiologia, 484: 121-131.

Garmendia, J.M., A. Sánchez-Mata and J. Mora. - 1998. Inventario de la macrofauna bentónica de sustratos blandos submareales de la Ría de Ares-Betanzos (NO de la Península Ibérica). N.A.C.C., 8: 209-231.

Glémarec, M. - 1964. Bionomie benthique de la partie orientale du Golfe de Morbihan. Cah. Biol. Mar., 5: 33-96.

Glémarec, M. - 1973. The bentic communities of the European North Atlantic continental shelf. Oceanogr. Mar. Biol. Annu. Rev., 11: 263-289.

Holte, B, E. Oug and S. Cochrane. - 2004. Depth-related benthic macrofaunal biodiversity patterns in three undisturbed north Norwegian fjords. Sarsia, 89: 91-101.

Junoy, J. - 1996. La Ría de Foz, comunidades bentónicas. Servicio de Publicaciones de la Diputación Provincial de Lugo, Spain.

Labrune, C., A. Grémare, J-M. Amouroux, R. Sardá, J. Gil and S. Taboada. - 2008. Structure and diversity of shallow soft-bottom benthic macrofauna in the Gulf of Lions (NW Mediterranean). Helg. Mar. Res., 62: 201-214.

Lastra, M., J. Mora, A. Sánchez and J. Palacio. - 1990. Comunidades bentónicas infralitorales de la Bahía de Santander (N de España). Cah. Biol. Mar., 31: 25-46.

López-Jamar, E. - 1981. Spatial distribution of the infaunal benthic communities of the Ría de Muros, North-West Spain. Mar. Biol., 63: 29-37. 
López-Jamar, E. - 1982. Distribución espacial de las comunidades bentónicas infaunales de la ría de Arosa. Bol. Inst. Esp. Oceanogr., 7(2): 255-268.

López-Jamar, E. and R.M. Cal. - 1990. El sistema bentónico de la zona submareal de la ría de Vigo. Macroinfauna y microbiología del sedimento. Bol. Inst. Esp. Oceanogr., 6: 49-60.

López-Jamar, E. and J. Mejuto. - 1985. Bentos infaunal en la zona submareal de la ría de La Coruña. I. Estructura y distribución espacial de las comunidades. Bol. Inst. Esp. Oceanogr., 2: 99-109.

López-Jamar, E. and J. Mejuto. - 1986. Evolución temporal de cuatro comunidades infaunales submareales de las Rías de Arosa y Muros. Resultados preliminares. Bol. Inst. Esp. Oceanogr., 3: 95-110.

López-Jamar, E. and J. Mejuto. - 1988. Infaunal benthic recolonization after dredging operations in La Coruña Bay, NW Spain. Cah. Biol. Mar., 29: 37-49.

Lourido, A., L. Gestoso and J.S. Troncoso. - 2006. Assemblages of the molluscan fauna in subtidal soft bottoms of the Ría de Aldán (northwestern Spain). J. Mar. Biol. Ass. UK, 86: 129-140.

Lourido, A., E. Cacabelos and J.S. Troncoso. - 2008a. Patterns of distribution of the polychaete fauna in subtidal soft bottoms of the Ría de Aldán (north-western Spain). J. Mar. Biol. Ass. UK, 88: 263-275.

Lourido, A., J. Moreira and J.S. Troncoso. - 2008b. Assemblages of peracarid crustaceans in subtidal sediments from the Ría de Aldán (Galicia, NW Spain). Helg. Mar. Res., 62: 289-301.

Maggiore, F. and E. Keppel. - 2007. Biodiversity and distribution of polychaetes and molluscs along the Dese estuary (Lagoon of Venice, Italy). Hydrobiologia, 588: 189-203.

Makra, A. and A. Nicolaidou. - 2000. Benthic communities of the inner Argolikos Bay. Belg. J. Zool., 130S1: 61-67.

Mastrototaro, F., A. Giove1, G. D'Onghia, A. Tursi, A. Matarrese1 and M.V. Gadaleta. - 2008. Benthic diversity of the soft bottoms in a semi-enclosed basin of the Mediterranean Sea. J. Mar. Biol. Ass. U.K., 88: 247-252.

Mirza, F.B. and J.S. Gray. - 1981. The fauna of benthic sediments from the organically enriched Oslofjord, Norway. J. Exp. Mar. Biol. Ecol., 54: 181-207.

Mora, J., M.A. García and R. Acuña. - 1982. Contribución al conocimiento de las poblaciones de la macrofauna bentónica de la Ría de Pontevedra. Oecol. Aquat., 6: 51-56.

Moreira, J. and J.S. Troncoso. - 2008. Inventario de la macrofauna bentónica de sedimentos submareales de la Ensenada de Baiona (Galicia, NO Península Ibérica). N.A.C.C., 16: 101-128.

Moreira, J., P. Quintas and J.S. Troncoso. - 2005. Distribution of the molluscan fauna in subtidal soft bottoms of the Ensenada de Baiona (NW Spain). Am. Malacol. Bull., 20: 75-86.

Moreira, J., P. Quintas and J.S. Troncoso. - 2006. Spatial distribution of soft-bottom polychaete annelids in the Ensenada de Baiona (Ría de Vigo, Galicia, north-west Spain). Sci. Mar., 70S3: 217-224.

Montaudouin, X. de and P.-G. Sauriau. - 2000. Contribution to a synopsis of marine species richness in the Pertuis Charentais Sea with new insights in soft-bottom macrofauna of the Marennes-Oléron Bay. Cah. Biol. Mar., 41: 181-222.
Nombela, M.A., F. Vilas and G. Evans. - 1995 Sedimentation in the mesotidal Rías Bajas of Galicia (north-western Spain): Ensenada de San Simón Inner Ría de Vigo. Spec. Publ. Int. Ass. Sediment., 24: 133-149.

Olabarria, C., V. Urgorri and J.S. Troncoso. - 1998. An analysis of the community structure of subtidal and intertidal benthic mollusks of the Inlet of Baño (Ría de Ferrol). Am. Malacol. Bull., 14: 103-120.

Olsgard, F., T. Brattegard and T. Holthe. - 2003. Polychaetes as surrogates for marine biodiversity: lower taxonomic resolution and indicator groups. Biodiversity Conserv., 12(5): 1033-1049(17).

Palacio, J., M. Lastra and J. Mora - 1991. Distribución vertical de la macroinfauna intermareal de la Ensenada de Lourizán (Ría de Pontevedra). Thalassas, 9: 49-62.

Pearson, T.H. and R. Rosenberg. - 1978. Macrobenthic succession in relation to organic enrichment and pollution of the marine environment. Oceanogr. Mar. Biol. Annu. Rev., 16: 229-311.

Petersen, C.G.J. - 1918. The sea-bottom and its production of fishfood. A survey of the work done in connection with the valuation of the Danish waters from 1883-1917. Rep. Dan. Biol. Stat., 25: 1-62.

Quintino, V., A.M. Rodrigues, F. Gentil and M.C. Peneda. - 1987. Macrozoobenthic community structure in the Lagoon of Albufeira, western coast of Portugal. J. Exp. Mar. Biol. Ecol., 106: 229-241

Rosenberg, R. - 1995. Benthic marine fauna structured by hydrodynamic processes and food availability. Neth. J. Sea Res., 34: 303-317.

Salzwedel, H., E. Rachor and D. Gerdes. D. - 1985. Benthic macrofauna communities in the German Bight. Veröff. Inst. Meeresforsch. Bremerhav., 20: 199-267.

Snelgrove, P.V.R. - 1998. The biodiversity of macrofaunal organisms in marine sediments. Biodiversity Conserv., 7: 1123-1132.

Ter Braak, C.J.F. - 1988. Canoco - A Fortran program for canonical community ordination by partial, detrended, canonical correspondence analysis, principal components analysis and redundancy analysis. Agricultural Mathematics Group, Ministry of Agriculture and Fisheries, Ithaca, New York

Thorson, G. - 1957. Bottom communities (sublittoral or shallow shelf). Geol. Soc. Am. Mem., 67: 461-534.

Toulemont, A. - 1972. Influence de la nature granulométrique des sédiments sur les structures benthiques. Baies de Douarnenez et D'Audierne (Ouest-Finistère). Cah. Biol. Mar., 13: 91-136.

Trask, P.D. - 1932. Origin and environment of source sediments of petroleum. Houston Gulf Publications Co. Houston.

Troncoso, J.S., V. Urgorri and J. Parapar. - 1993. Cartografía de los moluscos infralitorales de sustratos duros de la Ría de Ares y Betanzos (Galicia, NO de España). Publ. Espec. Inst. Esp. Oceanogr., 11: 131-137.

Wentworth, C.K. - 1922. A scale of grade and class terms for clastic sediments. J. Geol., 30: 377-392.

Scient. ed.: W.E. Arntz

Received September 4, 2009. Accepted February 10, 2010.

Published online August 16, 2010. 